\title{
Electrical stunning in South American catfish (Rhamdia quelen) using direct current waveform: welfare and meat quality
}

\section{Daniel Santiago Rucinque ${ }^{1}\left(\right.$ Andrea Gomes Chalbaud Biscaia ${ }^{1}\left([)\right.$ André Luiz Watanabe $^{2} \odot$ Carla Forte Maiolino Molento ${ }^{1^{*}}$}

${ }^{1}$ Laboratório de Bem-estar Animal (LABEA), Setor de Ciências Agrarias, Universidade Federal do Paraná, 80035-050, Curitiba, PR, Brasil. E-mail: carlamolento@ufpr.br. "Corresponding author.

${ }^{2}$ Estação de Pesquisa em Piscicultura e Ecologia de Espécies Nativas do Reservatório da ITAIPU Binacional, Foz do Iguaçu, PR, Brasil.

ABSTRACT: In Brazil, humane slaughter regulation is in use since 2000; however it is not applied to fish. This paper studied parameters for electrical stunning using direct current waveform in South American catfish (Rhamdia quelen) and its subsequent effects on muscular pH and rigor mortis. Seventy fish were allocated into two groups. In group 125, fish were stunned using 125 Volts (V), $30 \mathrm{~Hz}$, duty cycle of $90 \%$ and $1.3 \mathrm{Amp}$ (A) applied for $30 \mathrm{~s}$; in group 400, fish were stunned with $400 \mathrm{~V}, 30 \mathrm{~Hz}$, duty cycle of $27 \%$, $0.9 \mathrm{~A}$, for $30 \mathrm{~s}$. Unconsciousness time was determined through behavioural assessment. After slaughter, ten fish from each group were refrigerated for both measurements muscular pH and rigor mortis index (RMI) at 0, 3, 6, 24, 72 and $120 \mathrm{~h}$. In 125, 14.4\% (5/35) of fish were not effectively stunned, in contrast with 400 in which $100 \%$ of fish (35/35) were effectively stunned. The unconsciousness duration was higher in 400 group (87.7 $\pm 16.1 \mathrm{~s})$ in contrast with group 125 $(66.6 \pm 16.1 \mathrm{~s})$. Until $6 \mathrm{~h}$ post mortem ninety percent of fish reached maximum rigor mortis (RMI=100\%).

Key words: animal welfare, fish, humane slaughter, meat quality, stunning, unconsciousness.

Insensibilização elétrica em Jundiá (Rhamdia quelen) usando corrente direta: bem-estar e qualidade da carne

RESUMO: No Brasil, a normativa de abate humanitário está em vigência desde 2000, no entanto tal norma não contempla peixes. O objetivo deste trabalho foi estudar os parâmetros para insensibilização elétrica em Jundiá (Rhamdia quelen) e seus efeitos sobre o pH muscular e o rigor mortis. Setenta peixes foram alocados em dois grupos. No grupo 125, os peixes foram insensibilizados usando 125 Volts (V), 30 Hz, duty cycle of $90 \%$ e $1.3 \mathrm{Amp}(\mathrm{A})$ durante $30 \mathrm{~s}$; no grupo 400, os peixes foram insensibilizados com $400 \mathrm{~V}, 30 \mathrm{~Hz}$, duty cycle of $27 \%$, $0.9 \mathrm{~A}$, durante $30 \mathrm{~s}$. O tempo de inconsciência foi determinado por avaliação comportamental. Após o abate, 10 peixes de cada grupo foram refrigerados para mensurações de pH muscular e o indice rigor mortis (RMI) às 0, 3, 6, 24, 72 e 120 h. No grupo 125, 14.4\% (5/35) dos peixes não foram efetivamente insensibilizados, em contraste com o grupo 400, em que 100\% dos peixes (35/35) foram efetivamente insensibilizados. A duração da inconsciência foi significativamente maior no tratamento 400, igual a $87.7 \pm 16.1 \mathrm{~s}$ em relação aos $66.6 \pm 16.1 \mathrm{~s}$ no 125 . Noventa por cento dos peixes atingiram o máximo rigor mortis (RMI=100\%) dentro das 6 h pós-abate. A insensibilização elétrica em Jundiá parece ser possível usando parâmetros do grupo 400, devido à duração de inconsciência maior que $60 \mathrm{~s}$.

Palavras-chave: abate humanitário, bem-estar animal, inconsciência, insensibilização, qualidade da carne, peixes.

\section{INTRODUCTION}

Global production of fish, crustaceans, molluscs and other aquatic animals continued to grow and reached 170.9 million tonnes in 2016. Aquaculture production was 80 million tonnes in 2016, an increase of 5.2\% from previous year (FAO, 2018a). According to website FAO statistics, in 2016, 509,285 tons of fish were produced in Brazil from aquaculture, presenting an increase of $5.4 \%$ in relation to the previous year (FAO, 2018b).
The South American catfish Rhamdia quelen (Osteichthyes, Teleostei, Siluriformes, Pimelodidae, Rhamdia), locally known as jundiá, is a promising species for Brazilian fish farming. The species Rhamdia quelen presents neotropical distribution, from Southwest Mexico to central Argentina (GOMES, et al., 2000). South American catfish production is 1,747 tons and represents $0.32 \%$ of Brazilian aquaculture (BRASIL, 2011). The estimates of South American catfish killed per year vary between 8,735 million to 582,000 , 
depending on the weight at slaughter $(0.2-3 \mathrm{~kg})$ (GOMES, et al., 2000). South American catfish are commonly used in polyculture with other species, such as tilapia (Oreochromis niloticus), common carp (Cyprinus carpio), grass carp (Ctenopharyngodon idella), big head carp (Aristichthys nobilis), silver carp (Hypoththalmichthys molitrix), African catfish (Clarias gariepinus), American catfish (Ictalurus punctatus) and pacu (Piaractus mesopotamicus) (OSTRENSKY et al., 2007). R. quelen lives naturally in lakes and deep wells of rivers, preferring calmer waters environments with sand and mud bottom, along the banks and vegetation. They hide among rocks and rotting logs, from which they come out at night looking for food (GOMES, et al., 2000). In experiments on larvae and fingerlings of South American catfish, marked aversion to light and search for dark places was observed (PIAIA et al., 1999).

Recently, with the intensification in animal production, concern about animal welfare has grown, most markedly in western culture. Animal welfare debate has tended to focus on terrestrial species. However, in a study on Norwegian perception about animal welfare ELLINGSEN et al. (2015) noted that fish welfare was considered important by the respondents. Additionally, highly educated Latin Americans consider fish as sentient animals and believe that fish should be included in the regulations of humane slaughter (RUCINQUE; et al., 2017). The slaughter methods used in fish are a critical point that can cause high degree of suffering in the large number of individual fish slaughtered annually for human consumption. Thus, in Norwegian and Swedish humane slaughter regulations, stunning of farmed fish is mandatory (NORWAY, 2009; RÖCKLINSBERG, 2015). However, humane slaughter regulation is applied in Brazil since 2000, although not applied to fish species (BRASIL, 2000). Public consultations to update such regulation were carried out and as a research group we contributed with information to include fish; however, in the last update in 2018 fish were not included.

Killing methods such as hypothermia in ice followed by evisceration and exsanguination cause high degree of suffering in conscious animals (ROBB \& KESTIN, 2002). In Brazil, most fish slaughterhouses apply hypothermia in ice during 20 min or more prior to bleeding, by cutting the gills (OLIVEIRA FILHO et al., 2014). Other methods considered as inhumane such as asphyxia, exsanguination, evisceration or filleting in conscious fish are also used (RUCINQUE et al., 2017). Conversely, humane slaughter is characterized by two steps of interventions: stunning, which is applied to induce unconsciousness and insensibility to pain stimuli for sufficient duration to secure that an animal does not recover during bleeding, and induction of death by bleeding (TERLOUW et al., 2016). It is evident that fish slaughter in Brazil is not humane.

Electricity is widely used for stunning poultry and red meat animals that are killed for food. The principle of electrical stunning is to disrupt the electrical activity in the brain. The technique involves placing electrodes on either side of the head to pass a current of sufficient intensity through the brain (TERLOUW et al., 2016). Effective electrical stunning is associated with the induction of seizure or a generalized epileptiform insult (COOK et al., 1995). In such state, animals are unconscious; and therefore, unable to sense pain (ROBB \& ROTH, 2003). The determination of unconsciousness can be achieved through electroencephalography (EEG) (ROBB et al., 2000) or behavioural assessment (KESTIN, et al., 2002).

In terms of meat quality aspects, rigor mortis and muscular $\mathrm{pH}$ are practical on-field indicators. Increased muscular activity, stress at slaughter and the consequent endocrine responses influence fish postmortem biochemical processes, mostly the anaerobic glycolysis and ATP degradation rate. This in turn influences the onset and release of rigor mortis, which is related to the involution rate of fish freshness. In this way, pre-slaughter stress leads to undesirable quality changes mostly in physical and freshness parameters (HUSS, 1995; POLI et al., 2005). The close interrelationship between endocrine acute stress responses and fish post-mortem biochemical processes suggested the relevance of not only haematic stress indicators like plasma cortisol, lactate and glucose, but also tissue stress indicators such as muscular $\mathrm{pH}$, lactate and ATP and its catabolites. The natural muscle $\mathrm{pH}$ of live fish is just above 7.0, typically about 7.3; however, this falls markedly after death as the fish goes through rigor mortis and glycogen is converted to lactic acid (HUSS, 1995; POLI et al., 2005). When fish is on complete rigor mortis, the filleting process tends to be less efficient and slower. The delay on the installation of rigor mortis facilitates the manual work of filleting, optimizing the time and procedure for the operator (POLI et al., 2005).

Thus, considering the relevant negative consequences of fish suffering both for animal welfare and product quality, this paper studied parameters for electrical stunning using direct current waveform in South American catfish (Rhamdia quelen) and its subsequent effects on muscular $\mathrm{pH}$ and rigor mortis. 


\section{MATERIALS AND METHODS}

\section{Animals and location}

Fish evaluated in this study (Rhamdia quelen) belonged to the "Estação de Pesquisa em Piscicultura e Ecologia de Espécies Nativas" (Research Station in Fish Farming and Ecology of Native Species) of ITAIPU Binacional hydropower plant, in the city of Foz do Iguaçu, Southwest of Parana, Brazil, where they were raised in cages located in the water reservoir. The experiments were carried out in September 2015. The methodology reported by RUCINQUE et al. (2018) as detailed below was followed.

The Itaipu reservoir has a flooded area of $1,350 \mathrm{~km}^{2}$ and three licensed aquaculture parks accounting for 24.9 ha for native fish farming (SILVA et al., 2012). Eighty male and female fish were raised during four months in cages of $7 \mathrm{~m}^{3}$ at a final density of $40 \mathrm{~kg} / \mathrm{m}^{3}$. Twenty-four hours before starting the experiment, healthy fish were randomly allocated and transported to an aquaculture laboratory (S $25^{\circ} 25^{\prime}$ $\left.46.678^{\prime \prime} \mathrm{O} 54^{\circ} 34^{\prime} 51.873^{\prime \prime}\right)$. Transport lasted $30 \mathrm{~min}$, then fish were placed into $2.4 \mathrm{~m}^{3}(1.88 \times 1.48 \times 0.89$ m) concrete tanks at a density of $17 \mathrm{fish} / \mathrm{m}^{3}$; fish were not fed during 48 hours prior to experiments, following the common pre-slaughter fasting practice in the industry. Fasting is used to reduce both the gut contend and the charge of gut microbiota. The water in the tank came from a reservoir and it was constantly renewed by a continuous flux $\left(10 \mathrm{~L} \mathrm{~s}^{-1}\right)$. Water quality parameters during the experiment were $\mathrm{pH}$ of $7.57 \pm 0.37$; dissolved oxygen $5.44 \pm$
$0.61 \mathrm{mg} \mathrm{L}{ }^{-1}$, and temperature $20.84 \pm 1.15^{\circ} \mathrm{C}$. The photoperiod was natural, $12 \mathrm{~h}$ of light and $12 \mathrm{~h}$ of darkness (RUCINQUE et al., 2018).

Six fish were used in a pilot study for testing the efficacy of currents to induce unconsciousness (Table 1). Hence, seventy 70 fish of $0.12 \pm 0.04 \mathrm{~kg}$ and a total length of $22.73 \pm 2.00 \mathrm{~cm}$ were allocated into two groups, 125 and 400. Rosner's formula for comparing two means was applied to define the minimum sampling size of 35 fish in each group (ROSNER, 2010), considering a $95.0 \%$ confidence interval and a power of $90.0 \%$. The values for mean and standard deviation of unconsciousness time for two different types of current $(51 \pm 26)$ and $(37 \pm 10)$ for stunning in tilapia were obtained from LAMBOOIJ et al. (2008).

In group 125 , fish were stunned with the input parameters: pulsed direct current waveform, 125 Volts (V), $30 \mathrm{~Hz}$ and duty cycle equal to $90 \%$ applied for $30 \mathrm{~s}$. In group 400, fish were stunned with pulsed direct current waveform, $400 \mathrm{~V}, 30 \mathrm{~Hz}$ and duty cycle equal to $27 \%$ applied for $30 \mathrm{~s}$. The output parameters were calculated and displayed by the equipment. Electrical parameters for each group were established according to the pilot study as well as the equipment capacity (KOLZ, 2008), with the aim of comparing two different values of voltage regarding to duration of unconsciousness (Table 1).

\section{Electrical stunning}

The backpack electrofisher (Smith Root LR-24, USA https://www.smith-root.com/ electrofishers/lr-24) was used for electrical stunning

Table 1 - Electrical parameters used in the pilot study to test stunning in six South American catfish (Rhamdia quelen).

\begin{tabular}{|c|c|c|c|c|c|c|c|c|c|}
\hline \multirow[t]{2}{*}{ Waveform } & \multicolumn{3}{|c|}{ Input parameters } & \multicolumn{3}{|c|}{$\begin{array}{l}\text { Output parameters - Average } \\
\text { (peak) }\end{array}$} & \multirow[t]{2}{*}{$\begin{array}{l}\text { Application } \\
\text { time (s) }\end{array}$} & \multicolumn{2}{|l|}{ Results } \\
\hline & $\begin{array}{l}\text { Tension } \\
\text { (V) }\end{array}$ & $\begin{array}{l}\text { Frequenc } \\
\mathrm{y}(\mathrm{Hz})\end{array}$ & $\begin{array}{l}\text { Duty } \\
\text { cycle } \\
(\%)\end{array}$ & $\begin{array}{l}\text { Power } \\
\text { Watts (W) }\end{array}$ & $\begin{array}{l}\text { Tension } \\
\text { (V) }\end{array}$ & $\begin{array}{l}\text { Curre } \\
\text { nt (A) }\end{array}$ & & $\begin{array}{l}\text { Effective } \\
\text { stunning }\end{array}$ & $\begin{array}{l}\text { Duration of } \\
\text { unconsciousness } \\
\text { (s) }\end{array}$ \\
\hline $\begin{array}{l}\text { Smoot direct } \\
\text { current }\end{array}$ & 205 & - & - & 295 (296) & $\begin{array}{l}193 \\
(193)\end{array}$ & $\begin{array}{l}1.3 \\
(1.3)\end{array}$ & 30 & Not & 0 \\
\hline $\begin{array}{l}\text { Pulse direct } \\
\text { current }\end{array}$ & 125 & 30 & 30 & $127(160)$ & $\begin{array}{l}123 \\
(123)\end{array}$ & $\begin{array}{l}1.0 \\
(1.3)\end{array}$ & 30 & Not & 0 \\
\hline $\begin{array}{l}\text { Pulse direct } \\
\text { current }\end{array}$ & 205 & 50 & 70 & $266(440)$ & $\begin{array}{l}204 \\
(204)\end{array}$ & $\begin{array}{l}1.3 \\
(2.2)\end{array}$ & 15 & Not & 0 \\
\hline $\begin{array}{l}\text { Pulse direct } \\
\text { current }\end{array}$ & 400 & 30 & 25 & $308(440)$ & $\begin{array}{l}204 \\
(204)\end{array}$ & $\begin{array}{l}1.5 \\
(2.2)\end{array}$ & 30 & Yes & 46 \\
\hline $\begin{array}{l}\text { Pulse direct } \\
\text { current }\end{array}$ & 125 & 30 & 90 & $142(157)$ & $\begin{array}{l}123 \\
(127)\end{array}$ & $\begin{array}{l}1.2 \\
(1.3)\end{array}$ & 30 & Yes & 60 \\
\hline $\begin{array}{l}\text { Pulse direct } \\
\text { current }\end{array}$ & 400 & 30 & 27 & $\begin{array}{l}288 \\
(1075)\end{array}$ & $\begin{array}{l}319 \\
(320)\end{array}$ & $\begin{array}{l}0.9 \\
(3.4)\end{array}$ & 30 & Yes & 50 \\
\hline
\end{tabular}

Ciência Rural, v.51, n.8, 2021. 
1 within a $75 \mathrm{H} \times 56 \mathrm{~W} \times 40 \mathrm{H}$ cm plastic box serving as 2 stunning tank, containing $80 \mathrm{~L}$ of fresh water coming

3 from the concrete tanks. The distance between the

4 ring-shaped and the wire-shaped electrodes was 40

$5 \mathrm{~cm}$. Water parameters were controlled to remain at

$620{ }^{\circ} \mathrm{C}$, dissolved oxygen $>6 \mathrm{mg} \mathrm{L}^{-1}$, $\mathrm{pH}$ between 6.5

7 and 7.5 and conductivity of $0.700 \mathrm{mS}$ (RUCINQUE et

8 al., 2018). Small quantities of salt were added to set the

9 conductivity to the required level (LINES \& KESTIN,

10 2004). Water measurements were using the Horiba

11 U-50 Series Multiparameter Water Quality Meters.
Fish were removed from the concrete tanks using a hand net and placed in the stunning tank. Fish swam freely during $30 \mathrm{~s}$ before stunning; they were stunned in pairs. A protocol to determine the unconsciousness duration through behavioural evaluations was followed (KESTIN et al., 2002) (Table 2). The same observer evaluated all fish to avoid confusing effects due to inter-observer variations.

The process of electrical stunning for all animals was recorded with a digital camera (Sony SteadyShot DSC-W320). Subsequently, the recordings were then analyzed to confirm the unconsciousness duration time for each fish, and the first observed consciousness indicator was registered. Immediately after the observation of the return to consciousness, each fish was placed in a plastic aquarium with $35 \mathrm{~L}$ of fresh water and $300 \mathrm{mg} \mathrm{L}^{-1}$ of benzocaine. When fish stopped opercular movements, which corresponds to stage 6 of anaesthesia (LAMBOOIJ et al., 2008), they were bled through gill-cutting in ice, for $3 \mathrm{~min}$. The carcasses were subsequently measured and weighed. The recordings were analysed to confirm the unconsciousness duration time for each fish, which was considered as ended when the first indicator of consciousness appeared, considering swimming, equilibrium, response to handling, response to painful stimuli, vestibulo-ocular reflex VOR and breathing (RUCINQUE et al., 2018).

\section{Muscular $\mathrm{pH}$ and rigor mortis}

First 10 fish from each group were identified and refrigerated in plastic boxes with ice. Both muscular $\mathrm{pH}$ and rigor mortis index (RMI) were measured at $0,3,6,24,72,120$ and 144 hours after slaughter. The proportion of ice per fish was $2: 1$. For $\mathrm{pH}$ determination, a $1 \mathrm{~cm}$-cut was performed in the skin to access the epaxial muscle, in order to insert the electrode linked to the $\mathrm{pH}$ meter (MS TECNOPON, mPA 2010). A new cut

Table 2 - Protocol to determine the unconsciousness duration through behavioural evaluations after electrical stunning in South American catfish (Rhamdia quelen), modified from Kestin et al., 2000.

\begin{tabular}{|c|c|c|c|c|c|c|}
\hline & \multicolumn{2}{|c|}{--------Self-initiated behaviour-------- } & \multicolumn{2}{|c|}{---------Response to stimuli--------- } & \multicolumn{2}{|c|}{------------Clinical reflexes----------- } \\
\hline & Swimming & Equilibrium & Handling & Prick & Eye roll & Breathing \\
\hline $\begin{array}{l}\text { Behaviour / } \\
\text { reflex }\end{array}$ & $\begin{array}{l}\text { Swimming } \\
\text { behaviour }\end{array}$ & Righting ability & $\begin{array}{l}\text { Response to } \\
\text { handling }\end{array}$ & $\begin{array}{l}\text { Response to } \\
\text { prick } \\
\text { on lip }\end{array}$ & $\begin{array}{l}\text { Vestibule-ocular } \\
\text { reflex VOR }\end{array}$ & $\begin{array}{l}\text { Rhythmic } \\
\text { opercular } \\
\text { activity }\end{array}$ \\
\hline Procedure & $\begin{array}{l}\text { Observe } \\
\text { spontaneous } \\
\text { swimming } \\
\text { behaviour }\end{array}$ & $\begin{array}{l}\text { Invert fish, } \\
\text { observe } \\
\text { righting } \\
\text { response }\end{array}$ & $\begin{array}{l}\text { Attempt to catch } \\
\text { by } \\
\text { tail and } \\
\text { administer } \\
\text { tail pinch, } \\
\text { observe } \\
\text { response }\end{array}$ & $\begin{array}{l}\text { Prick lightly on } \\
\text { lip } \\
\text { with enough } \\
\text { pressure to cause } \\
\text { pricking } \\
\text { sensation to } \\
\text { human, observe } \\
\text { response }\end{array}$ & $\begin{array}{l}\text { Observe eye } \\
\text { movement when } \\
\text { fish } \\
\text { is rolled from } \\
\text { side to } \\
\text { side through the } \\
\text { perpendicular }\end{array}$ & $\begin{array}{l}\text { Observe } \\
\text { opercula for } \\
\text { rhythmic } \\
\text { movement }\end{array}$ \\
\hline $\begin{array}{l}\text { Recovery of } \\
\text { consciousness } \\
\text { after shift off } \\
\text { the current }\end{array}$ & $\begin{array}{l}\text { Slow or } \\
\text { abnormal } \\
\text { swimming, eg, } \\
\text { upside } \\
\text { down or } \\
\text { normal } \\
\text { swimming }\end{array}$ & $\begin{array}{l}\text { Slow to right or } \\
\text { Quickly rights }\end{array}$ & $\begin{array}{l}\text { Only slow or } \\
\text { feeble } \\
\text { response after } \\
\text { tail } \\
\text { pinch(s) or } \\
\text { immediate } \\
\text { vigorous } \\
\text { escape attempt } \\
\text { on } \\
\text { first touch/pinch }\end{array}$ & $\begin{array}{l}\text { Slow and } \\
\text { reduced } \\
\text { response or } \\
\text { head shake or } \\
\text { escape attempt }\end{array}$ & $\begin{array}{l}\text { Partial VOR or } \\
\text { one } \\
\text { eye shows VOR } \\
\text { or eyes roll } \\
\text { relative to } \\
\text { the head while } \\
\text { attempting to } \\
\text { remain upright } \\
\text { when } \\
\text { fish is rolled }\end{array}$ & $\begin{array}{l}\text { Slow or } \\
\text { irregular } \\
\text { movement or } \\
\text { regular } \\
\text { opercula } \\
\text { movement }\end{array}$ \\
\hline
\end{tabular}


was made in each measurement, alternating the left and right muscles. The $\mathrm{pH}$ electrode was calibrated every 10 measurements.

Rigor mortis index was calculated according to BITO et al. (1983), using the following formula:

$$
\operatorname{RMI}(\%)=\left[\left(L_{0}-L_{T}\right) / L_{0}\right] \times 100
$$

Where $L_{0}(\mathrm{~cm})$ is the vertical distance between the base of the caudal fin and the table surface, measured immediately after slaughter, and $L_{T}(\mathrm{~cm})$ is the vertical distance between the base of the caudal fin and the table surface at selected time intervals (CONCOLLATO et al., 2014).

For the other 25 fish of each group, carcasses were filleted following the normal processing procedure. This procedure was done by trained personnel, so that they could identify haemorrhages and spinal fractures in the fillets or carcasses (RUCINQUE et al., 2018).

\section{Statistical analyses}

The Shapiro-Wilk test was used to verify the normality of data in each variable. The variables unconsciousness duration time and latency until the first spasm presented normal distribution, and the variables number of spasms, muscular $\mathrm{pH}$ and rigor mortis index did not show a normality pattern. For comparisons between treatments, the t-test and the Mann-Whitney test were applied to parametric and non-parametric data, respectively. The Kruskal-Wallis test was used to compare different measurement times within the same group. The Fisher's exact test was used to compare proportion of animals performing specific behaviours between treatments. Analyses were performed using Minitab software, version 17.

\section{RESULTS AND DISCUSSION}

In group 125 a total of $14.4 \%(5 / 35)$ fish were not effectively stunned, in contrast with group 400 , in which $100 \%$ of fish $(35 / 35)$ were effectively stunned $(P=0.054)$. The five fish from group 125 that were not effectively stunned were excluded from subsequent behavioural assessments. The lower voltage used in group 125 may have influenced the final current in a critical manner. In African catfish (Clarias gariepinus), voltages of 223, 225, 232 and $264 \mathrm{~V}$ at $50 \mathrm{~Hz}$ applied for $1 \mathrm{~s}$ in a tank with fresh water did not cause unconsciousness (LAMBOOIJ et al., 2006). Particularly, four of these fish (4/5) were not effectively stunned (group 125); they were located in the lower left corner as shown in figure 1. Probably, in this position, the current did not effectively pass through the brain.
Immediately after the current was turned on fish instantly lost behavioural responses and reflexes which were indicators of consciousness: fish stopped swimming, lost equilibrium, did not respond to painful stimuli, stopped opercular movements and did not show any vestibulo-ocular reflex. Such results are in agreement with studies in tilapia (LAMBOOIJ et al., 2008), salmon (ROBB \& ROTH, 2003) and trout (ROBB et al., 2002). When the electrical current was turned off, most of fish $(73.3 \%$ in 125 ; $80.0 \%$ in 400 ) presented open mouth and operculum, with no difference between groups $(P=0.763)$. Subsequently, fish showed spasms along the length of the body. The proportion of fish that had spams was similar between groups $(P=0.204)$, with a total of $30.0 \%$ in 125 and $48.6 \%$ in 400 . The median (min-max) number of spasms was similar between groups $(P=0.978)$, with $6.0(2.0-17)$ spasms for 125 , and $6.0(1.0-28)$ for 400 . The latency until the first spasm was different among groups $(\mathrm{P}<0.01)$ with mean equal to $24.0 \pm 7.6 \mathrm{~s}$ for 125 and 47.9 $\pm 16.5 \mathrm{~s}$ for group 400. Spasms ceased when fish performed breathing movements. Data of the assessed post-stunning behaviour are presented on figure 2 .

The behaviours observed in this study were also reported by VEIT et al. (2017) using sinusoidal waveform, different frequencies $(50,100$, $300,500$ and $1000 \mathrm{~Hz})$ and two electrical fields (128 or $256 \mathrm{~V})$ in a tank $(66 \times 43 \times 19 \mathrm{~cm}, \mathrm{~L} \times \mathrm{W} \times \mathrm{H})$ with fresh water during $5 \mathrm{~s}$, also in Rhamdia quelem. Fish remained electro-immobilized and showed a tonic phase of epileptiform insult, with open mouth and opercula and fins away from the body. Effective stunning leads to tonic/clonic seizures, which are considered a sign for unconsciousness (EFSA, 2004). Electrical stunning can provoke immediate loss of

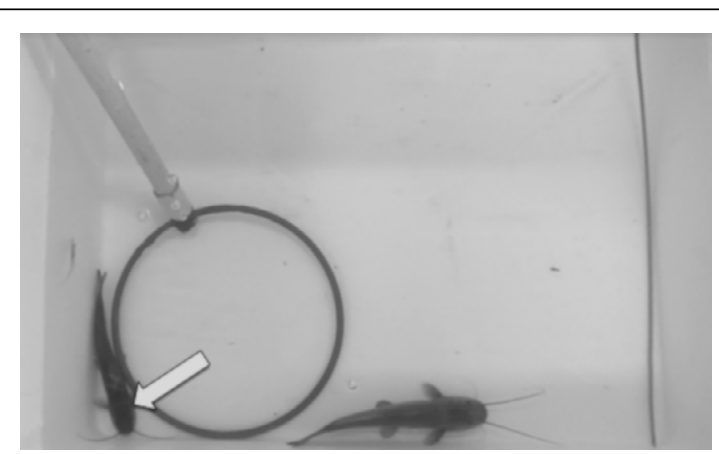

Figure 1 - The arrow indicates the position of 4/5 South American catfish (Rhamdia quelen) that were not effectively stunned. 
consciousness in fish; it is based on the induction of a general epileptiform insult, called grand mal or seizure-like state, caused by an electrical current going through the brain (LAMBOOIJ et al., 2010). This epileptic process is characterized by rapid and extreme depolarization of the neuronal membrane potential (LAMBOOIJ et al., 2014). The brain is unable to respond to stimuli, and there is a consensus that a vertebrate animal is unconscious and thus cannot experience pain during a generalized epileptiform insult (LAMBOOIJ et al., 2014).

When measured on the EEG, this insult consisted of relatively small waves increasing in amplitude in the tonic phase and decreasing in
A

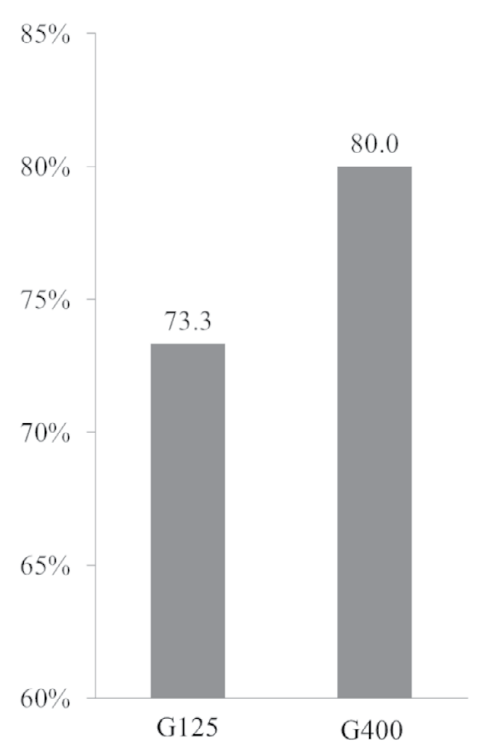

C

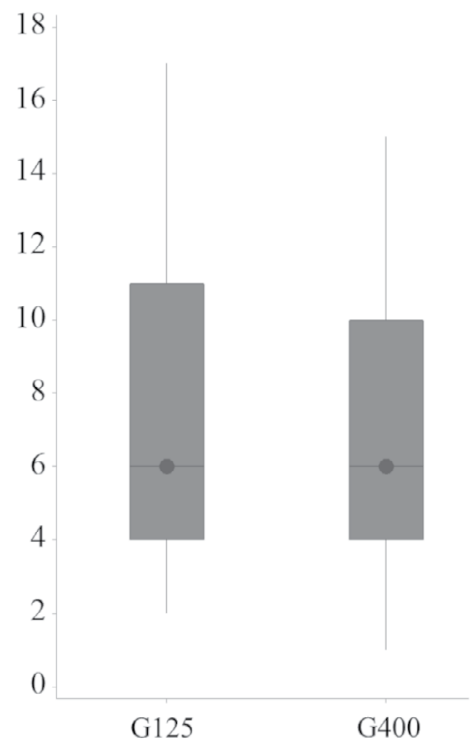

B

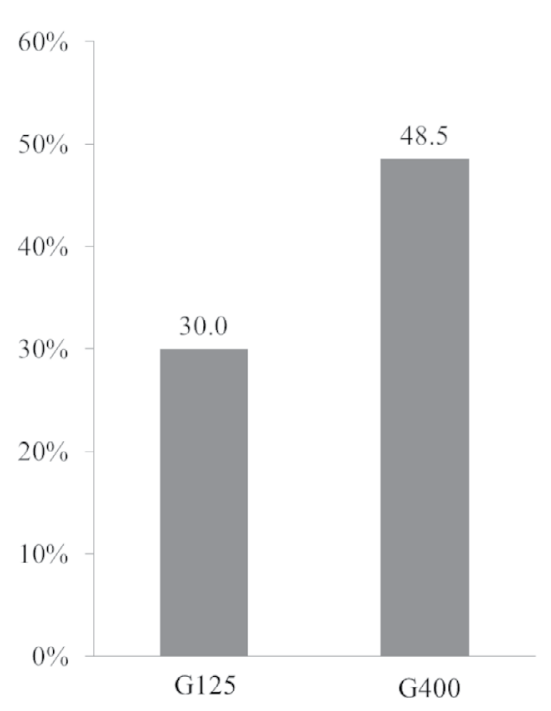

D

60 b $48.5 \pm 16.5$

40

30

20

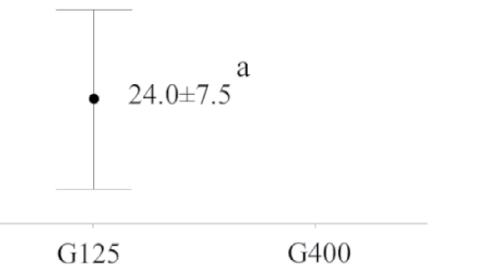

Figure 2 - Proportion of South American catfish (Rhamdia quelen) with open mouth and operculum (A), spasms (B), median number of spasms (C), and median latency (s) for the first spasm (D); different letters indicate differences between groups $(\mathrm{P}<0.05)$. 
frequency in the clonic phase to result ultimately in a period of strong depression of electrical activity as described in pigs, sheep, calves and fish (LAMBOOIJ et al., 2006). The general epileptiform insult on the EEG of broiler chickens, ostriches and eels is characterized by a tonic/clonic phase and an exhaustion phase (LAMBOOIJ et al., 2004). Probably, the behaviours observed in our study for South American catfish (Rhamdia quelen) indicate a tonic/clonic phase and, thus, unconsciousness. Such finding can improve fish welfare at slaughter, due to the possibility of replacing the use of hypothermia in Brazilian abattoirs (MENDES, 2015; OLIVEIRA FILHO et al., 2014; PEDRAZZANI et al., 2009). PEDRAZZANI et al, (2009) observed a median time of $750 \mathrm{~s}$ for the loss of all behavioural indicators of consciousness in Nile tilapia subjected to hypothermia, indicating a high degree of suffering. Therefore, methods that meet human slaughter principles must be validated to replace the hypothermia at slaughter of fish in Brazil.

The open operculum and mouth in the absence of spasms are suggestive of tonic phase and the spasms reflect the onset of clonic phase. It was not possible to identify an exhaustion phase because when fish ceased spasms, they initiated breathing movements. In African catfish (Clarias gariepinus) stunned with $291 \pm 5 \mathrm{~V}$ and $1.60 \pm 0.11$ A during $1 \mathrm{~s}$ in fresh water, the characteristics of a general epileptiform insult on the EEG were observed. The tonic, the clonic and the exhaustion phase were $7 \pm 3,12 \pm 7$ and $9 \pm 6$ s on the EEG, respectively (LAMBOOIJ et al., 2006). The latency to first spasms in South American catfish was longer in group 400, possibly related to the higher voltage used as compared to group 125. In trout exposed to electrical field using a sinusoidal waveform and $50 \mathrm{~Hz}$, (ROBB et al., 2002), the proportional relationship between current magnitude (V) on survival and the time to recovery of opercular movements was also demonstrated. The post-stunning behaviours observed, open mouth and operculum, spams and latency until the first spasm, suggest effective unconsciousness in South American catfish (Rhamdia quelen) under the described experimental conditions. However, before the application of electrical stunning at preslaughter, the electrical parameters for induction of unconsciousness should be validated measuring brain activity through EEG, considering an exposition time of at most $1 \mathrm{~s}$.

A total of $89 \%(58 / 65)$ of fish showed breathing as first response after electrical stunning. Breathing seems to be a promising indicator, considering the correlation between the incidence of recovery of Visual Evoked Responses through EEG and initiation of opercular movements in Atlantic salmon (ROBB \& ROTH, 2003). Other first behavioural responses in the present study were swimming (4/65), eye roll (2/65) and equilibrium $(1 / 65)$. Hence, opercular movements seem to constitute an important behavioural indicator of consciousness recovery after electrical stunning in South American catfish, which can be easily applied in the field.

According to figure 3 , the mean duration of unconsciousness was less in $125(62.6 \pm 15.4 \mathrm{~s})$ in contrast with $400(87.7 \pm 21.6 \mathrm{~s})(P<0.01)$. The unconsciousness duration time was higher in 400 , possibly due to higher voltage $(400 \mathrm{~V})$ in contrast with $125(125 \mathrm{~V})$. In a study on South American catfish (Rhamdia quelen) submitted to electrical stunning VEIT et al. (2017) observed that all fish recovered responses to painful stimulation and VOR after 8.5 to $57.3 \mathrm{~s}$, LAMBOOIJ et al. (2006) reported $28 \pm 8 \mathrm{~s}$ of unconsciousness in African catfish stunned through a voltage of $291 \pm 5 \mathrm{~V}, 1.60 \pm 0.11$ A during $1 \mathrm{~s}$. LAMBOOIJ (2014) reported that $40 \mathrm{~s}$ may be a suitable period of unconsciousness to facilitate exsanguination and onset of death in unconscious animals. In broiler chickens, the minimum duration of $60 \mathrm{~s}$ of unconsciousness is required for effective

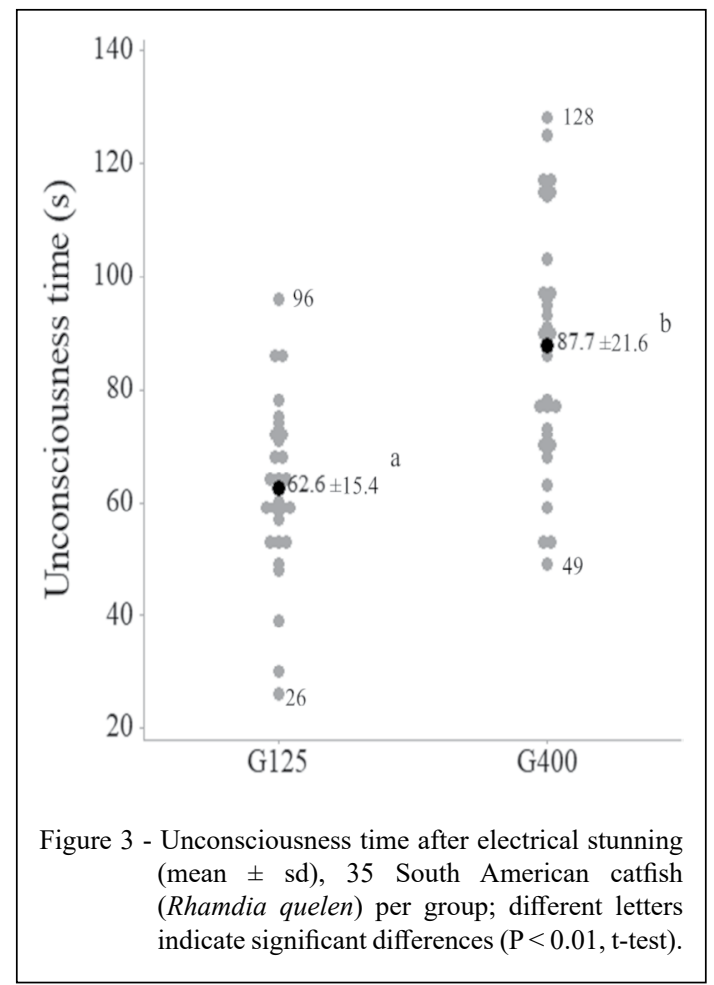

Ciência Rural, v.51, n.8, 2021. 
stunning, assuming that a neck cut is performed within $30 \mathrm{~s}$ after stunning (HINDLE et al., 2010). Nevertheless, fish should be bled immediately following stunning to guarantee that the fish does not recover. Thus, stunning of South American catfish for humane slaughter may be possible considering such parameters: pulsed direct current waveform, $400 \mathrm{~V}$, $30 \mathrm{~Hz}$, duty cycle of $27 \%$ and $0.8 \mathrm{~A}$ applied for 30 $\mathrm{s}$, since they induced unconsciousness that lasted $87.7 \pm 21.6$ s. The use of electroencephalography (EEG) for validation of electrical parameters for stunning together with the precautionary principle approach is suggested for further studies before onfield application of our results. The observation of behaviour does not allow differentiation between electro-immobilization or paralysis and real stunning with the loss of consciousness induced by the current. Knowledge regarding the duration of unconsciousness is also needed, as fish must be unconscious during the bleeding process until death.

Probably, the current peak has an important role because it was equal to $3.3 \mathrm{~A}$ in 400 , coinciding with longer unconsciousness $(87.7 \pm 21.6 \mathrm{~s})$, different from 1.3 A in $125(62.6 \pm 15.4 \mathrm{~s})$ (Figure 4). In South American catfish stunned through different currents and frequencies, VEIT et al. (2017) observed a significant effect of frequency on the apparent stun duration. DASKALOVA \& PAVLOV (2015) studied the effectiveness of tail-first dry electrical stunning for turbot (Scophthalmus maximus) and common sole (Solea solea). The authors used a current peak of 2.39 $\pm 0.91 \mathrm{~A}$ for turbot and 1.22 $\pm 0.68 \mathrm{~A}$ for sole applied by $1 \mathrm{~s}$ to induce unconsciousness during $15.1 \pm 9.4$ $\mathrm{s}$ and $13.6 \pm 12.2 \mathrm{~s}$ for turbot and sole, respectively (DASKALOVA \& PAVLOV, 2015). Thus, the results on unconsciousness duration time in 400 in this study may be related to the current peak.

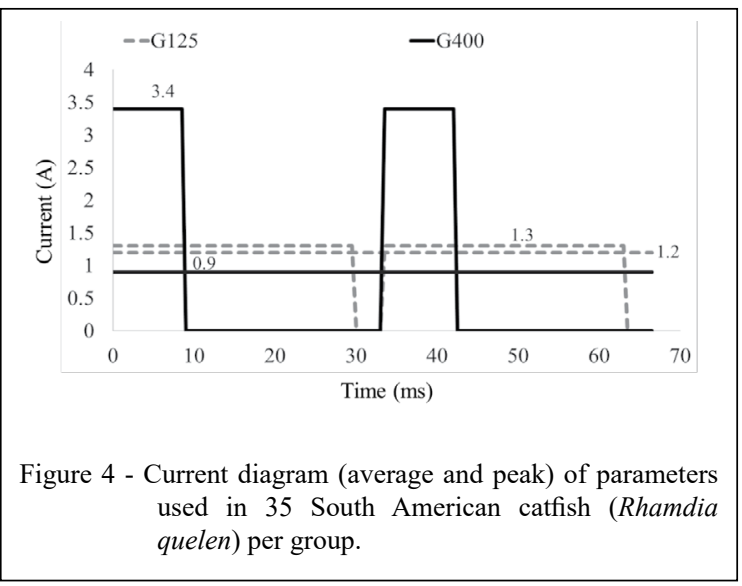

Immediately after slaughter the $\mathrm{pH}$ values (median, min-max) were 6.65 (6.20-6.90) for 125 and $6.70(6.40-7.10)$ for 400 (Figure 5) $(P=0.236)$. Similar values (6.50 to 6.75) were observed in (Rhamdia quelem) submitted to electrical stunning (VEIT et al., 2017). Higher values were observed in African catfish slaughtered by cranial spiking, the initial $\mathrm{pH}$ of the muscle immediately after death was 7.10. It decreased to 6.00 within 4 days, and then gradually increased to 7.25 at the lapse of 18 days storage period, in which the fish were organoleptically unacceptable (ADOGA et al., 2010). MANTHEY et al. (1988) also reported values of $\mathrm{pH}$ equal to $6.2 \pm 0.2$ and $6.1 \pm 0.5$ at 24 hours and 10 days after slaughter, respectively, in European catfish (Silurus glanis) stunned with a blow to the head, eviscerated and bled. Other methods of humane slaughter, as percussion, improve the quality of meat (ROBB \& KESTIN, 2002). In Atlantic cod (Gadus morhua L.) stunned by $\mathrm{CO}_{2}$, lower $\mathrm{pH}$ values after slaughter were observed, in comparison with fish stunned by percussion (KRISTOFFERSEN et al., 2006). Therefore, electrical stunning in South American catfish does not seem to significantly alter the values of muscle $\mathrm{pH}$.

The values of $\mathrm{pH}$ for South American catfish were similar in 125 and 400 in all the measurement times $(\mathrm{p}>0.05)$. The initial reduction in $\mathrm{pH}$ could be attributed to post mortem glycolysis which led to accumulation of lactic acid, which in turn lowered the $\mathrm{pH}$ of the muscle (HUSS, 1995). Brazilian regulation requires a $\mathrm{pH}$ of less than 7.0 in the muscle of fish (BRASIL, 2017), therefore the values of muscular $\mathrm{pH}$ in South American catfish are in concordance with such regulation. Our results showed that electrical

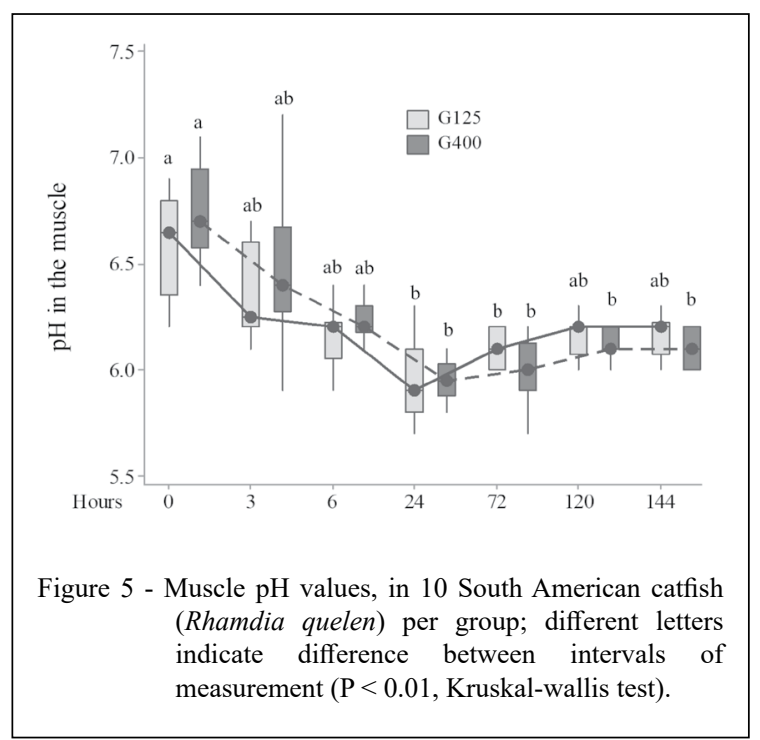


stunning does not significantly affect the $\mathrm{pH}$ values in South American catfish, as they are in the range allowed by the Brazilian legislation.

Until $6 \mathrm{~h}$ post mortem ninety percent of fish reached maximum rigor mortis (RMI $=100 \%$ ) (Figure 6). The delay in the onset and resolution of rigor mortis extend the shelf life of the fish (TEJADA, 2009). During pre-rigor phase, fish flesh remains in a state of freshness. Deterioration sets in when relaxation starts, in post-rigor period. In general, the slower the rate of progress of rigor mortis, the longer is the shelf-life of the fish (POLI et al., 2005). A prolongation of pre-rigor period can be achieved by delaying the onset of rigor mortis, decreasing the rate of progress of rigor mortis or by both, which are obviously of great commercial importance.

Increased muscular activity, stress at slaughter and endocrine responses may highly influence fish post mortem biochemical processes, mostly the anaerobic glycolysis and ATP degradation rate (HUSS, 1995). Delay the onset of rigor is particularly important as fish meat in pre-rigor state is considered good for the market (ISLAMI et al., 2014). In a total of $90.0 \%$ of fish in 125 and $60.0 \%$ in 400 the onset resolution of rigor mortis occurred at $72 \mathrm{~h}$, without significant differences $(P$ $=0.381)$. In African catfish slaughtered by cranial spiking, ADOGA et al. (2010) reported that complete relaxation $(35 \%)$ occurred within $12 \mathrm{~h}$ after death, with no sign of spoilage, since fish deterioration begins only after the resolution of rigor mortis (POLI et al., 2005). Nevertheless, ADOGA et al. (2010) observed African catfish in acceptable sensorial condition up to 12 days in ice storage, despite onset the resolution of rigor 12 hours after death. Humane

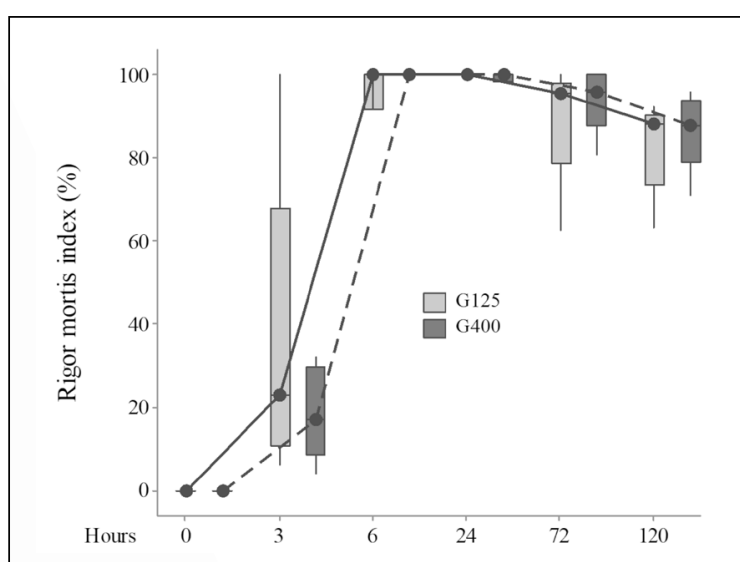

Figure 6 - Values of rigor mortis index (\%) in 10 South American catfish (Rhamdia quelen) per group. slaughter methods can delay the onset and resolution of rigor mortis in comparison to stunning with $\mathrm{CO}_{2}$ (POLI et al., 2005; ROTH et al., 2002). In addition, the pre-slaughter process which involves fasting, crowding and transport from net cages to stunning tanks might influence muscle energy reserves and thus rigor mortis resolution. Electrical stunning in South American catfish accelerates the resolution of rigor mortis. It is important that future studies determine the quality of the meat for human consumption.

Carcass damage as muscle haemorrhages or broken vertebral column might occur when electrical stunning is used, especially when fish are immersed in water during stunning (VAN DE VIS et al., 2014). In a study on South American catfish stunned using a sinusoidal waveform with $5 \mathrm{~s}$ of duration, different frequencies $(50,100,300,500$, or $1000 \mathrm{~Hz}$ ) and electrical fields (128 or $256 \mathrm{~V} \mathrm{~m}^{-1}$ ), VEIT et al, (2017) reported spinal fractures in $62 \%$ of fish. No problems were observed in the carcass quality in our study. Fillets and carcass did not show any haemorrhages, blood spotting in the meat, external damage or vertebral fracture. Perhaps, the electric parameters used are safe in terms of avoiding bleeding or fractures in the carcass.

New technologies are required to implement methods that meet the criteria for humane slaughter in fish, allowing for complete substitution of immersion in water and ice used in Brazil. New studies assessing unconsciousness by EEG as well as searching for methods with longer unconsciousness duration are recommended.

\section{CONCLUSION}

Electrical stunning in South American catfish (Rhamdia quelen) is possible through pulse direct current, 400 Volts, $30 \mathrm{~Hz}$, duty cycle of $27 \%$ and $0.9 \mathrm{~A}$ applied for $30 \mathrm{~s}$, and the unconsciousness thus produced seems to last an adequate period of time to allow for death, avoiding the risk of the animals return to a conscious state. Additionally, this stunning method did not cause significant alterations on muscle $\mathrm{pH}$ values. The electrical parameters employed seem safe in terms of avoiding muscle bleeding or fractures in the carcass. Validation of our results with electroencephalographic studies is warranted.

\section{ACKNOWLEDGEMENTS}

This study was partly financed by the Coordenação de Aperfeiçoamento de Pessoal de Nível Superior - Brasil (CAPES) - Finance Code 001 through a scholarship for the first author. The authors thank the staff of Estação de Pesquisa em Piscicultura e 
Ecologia de Espécies Nativas (EPPEEN) - ITAIPU Binacional hydropower plant, for the support on the project.

\section{BIOETHICS AND BIOSSECURITY COMMITTEE APPROVAL}

This experiment was approved by the Ethics Committee for Animal Use of the Agricultural Sciences Campus of the Universidade Federal do Paraná (Universidade Federal do Estado do Paraná (UFPR), Brazil), during session on August 27, 2015, and it is registered under protocol number $058 / 2014$.

\section{DECLARTION OF CONFLICT OF INTEREST}

The authors declare no conflict of interest. The founding sponsors had no role in the design of the study; in the collection, analyses, or interpretation of data; in the writing of the manuscript, and in the decision to publish the results.

\section{AUTHORS' CONTRIBUTIONS}

All authors contributed equally for the conception and writing of the manuscript. All authors critically revised the manuscript and approved of the final version.

\section{REFERENCES}

ADOGA, I. J et al. Studies on the post-mortem changes in African Catfish (Clarias angullaris) during ice - storage. New York Science Journal, v.3, n.6, p.96-101, 2010. Available from: <http:// www.sciencepub.net/newyork/ny0306/14_2646_ny0306_96_101. pdf $>$. Accessed: Jan. 21, 2016.

BRASIL. Instrução Normativa $\mathrm{n}^{\circ}$ 3, de 07 de janeiro de 2000. Regulamento técnico de métodos de insensibilização para o abate humanitário de animais de açougue. S.D.A./M.A.A. 24 de janeiro de 2000. Brasilia, 2000. Available from: <http://www.agricultura.gov. br/assuntos/sustentabilidade/bem-estar-animal/arquivos/arquivoslegislacao/in-03-de-2000.pdf $>$. Accessed: May, 03, 2014.

BRASIL. Boletim estatístico da pesca e aquicultura. Brasilia, 2011. Available from: <http://www.mpa.gov.br/files/docs/ Boletim_MPA_2011_pub.pdf $>$. Accessed: Jan. 2, 2016.

BRASIL. Decreto № 9.013 Regulamenta a inspeção industrial e sanitária de produtos de origem animal. DE 29 DE MARÇO DE 2017, [S.1.], 2017. Available from: $<\mathrm{http} / /$ www.planalto.gov.br/ccivil 03/ ato20152018/2017/decreto/D9013.htm>. Accessed: Feb. 9, 2017.

CONCOLLATO, A. et al. Effect of carbon monoxide for Atlantic salmon (Salmo salar L.) slaughtering on stress response and fillet shelf life. Aquaculture, v.433, p.13-18, 2014. Available from: $\quad<$ https://www.sciencedirect.com/science/article/abs/pii/ S0044848614002713?via\%3Dihub>. Accessed: Feb. 2, 2015. doi: 10.1016/j.aquaculture.2014.05.04.

COOK, C. J. et al. The effect of electrical head-only stun duration on electroencephalographic-measured seizure and brain amino acid neurotransmitter release. NULL: Meat Science, 1995. v.40, n.2, p.137-147. Available from: <https://www.sciencedirect.
com/science/article/abs/pii/0309174094000437?via\%3Dihub>. Accessed: Mar. 3. 2017. doi: 10.1016/0309-1740(94)00043-7.

DASKAlOVA, A. H.; PAVLOV, A. I. Effect of two stunning methods on postmortem muscle $\mathrm{pH}$ and meat quality of common carp (Cyprinus carpio L.). Bulgarian Journal of Veterinary Medicine, v.18, n.1, p.83-90, 2015. Available from: <http:// tru.uni-sz.bg/bjvm/BJVM-March\%202015\%20p.83-90.pdf>. Accessed: Mar. 3, 2017. doi: 10.15547/bjvm.822.

EFSA (EUROPEAN FOOD SAFETY AUTHORITY). Opinion of the Scientific Panel on Animal Health and Welfare (AHAW) on a request from the Commission related to welfare aspects of the main systems of stunning and killing the main commercial species of animals. EFSA Journal, v.45, p.1-241, 2004 Available from: $<$ https://www.efsa.europa.eu/en/efsajournal/pub/45>. Accessed: May, 29, 2018. doi: 10.2903/j.efsa.2004.45.

ELLINGSEN, K. et al. Who cares about fish welfare?: a Norwegian study. British Food Journal, v.117, n.1, p.257-273, 2015. Available from: <https://www.emerald.com/insight/content/ doi/10.1108/BFJ-08-2013-0223/full/html>. Accessed: Jun. 15, 2016. doi: 10.1108/BFJ-08-2013-0223.

FAO. Fisheries and Aquaculture Information and Statistics Branch. 2018b. Available from: <http://www.fao.org/figis/ servlet/SQServlet?file=/usr/local/tomcat/8.5.16/figis/webapps/ figis/temp/hqp_1751566751345398709.xml\&outtype $=$ html $>$. Accessed: Oct. 3, 2019.

FAO (FOOD \& AGRICULTURE ORGANISATION). FAO yearbook. Fishery and Aquaculture Statistics 2016. Rome: [s.n.], 2018a. Accessed: Oct. 23, 2018.

GOMES, L. D. C. et al. Biologia do jundiá Rhamdia quelen (Teleostei, Pimelodidae). Ciência Rural, v.30, n.1, p.179185, 2000. Available from: <https://www.scielo.br/scielo. php? script $=$ sci_arttext\&pid $=$ S0103-84782000000100029\&ln $\mathrm{g}=\mathrm{pt} \& \mathrm{t} \operatorname{lng}=\mathrm{pt}>$. Accessed: Jan. 15, 2016. doi: 10.1590/S010384782000000100029 .

HINDLE, V. et al. Animal welfare concerns during the use of the water bath for stunning broilers, hens, and ducks. Poultry Science, v.89, n.3, p.401-412, 2010. Available from: <http://www.ncbi. nlm.nih.gov/pubmed/20181854>. Accessed: Nov. 25, 2015. doi: $10.3382 /$ ps.2009-00297.

HUSS, H. Quality and quality changes in fresh fish. Fao Fisheries Technical Paper - 348, Rome, 1995. Available from: <http://www.fao.org/docrep/V7180E/V7180E00.HTM>. Accessed: Nov. 24, 2015.

ISLAMI, S. N. et al. Rigor index, fillet yield and proximate composition of cultured striped catfish (Pangasianodon hypophthalmus) for its suitability in processing industries in Bangladesh. Journal of fisheries, v.2, n.3, p.157-162, 2014. Accessed: Jan. 28, 2016.

KESTIN, S. et al. Protocol for assessing brain function in fish and the effectiveness of methods used to stun and kill them. Veterinary Record, v.150, p.302-307, 2002 Available from: <https://pubmed. ncbi.nlm.nih.gov/11915866/>. Accessed: Mar. 18, 2014. doi: 10.1136/vr.150.10.302.

KOLZ, A. L. Understanding Smith-Root LR-24 equipment specifications. North American Journal of Fisheries 
Management, v.28, n.5, p.1563-1567, 2008. Available from: $<$ http://www.tandfonline.com/doi/abs/10.1577/M08-013.1> Accessed: Nov. 24, 2015. doi: 10.1577/M08-013.1.

KRISTOFFERSEN, S. et al. Slaughter stress, postmortem muscle $\mathrm{pH}$ and rigor development in farmed Atlantic cod (Gadus morhua L.). International Journal of Food Science \& Technology, v.41, n.7, p.861-864, 2006. Available from: <https://ifst.onlinelibrary. wiley.com/doi/abs/10.1111/j.1365-2621.2005.01149.x>. Accessed: Jul. 7, 2014. doi: 10.1111/j.1365-2621.2005.01149.x.

LAMBOOIJ, E. et al. Head-only electrical stunning and bleeding of African catfish (Clarias gariepinus): assessment of loss of consciousness. Animal Welfare, v.13, p.71-76, 2004. Available from: <https://www.ingentaconnect.com/content/ufaw/ aw/2004/00000013/00000001/art00011>. Accessed: Oct. 16, 2014.

LAMBOOIJ, E. et al. Assessment of electrical stunning in fresh water of African Catfish (Clarias gariepinus) and chilling in ice water for loss of consciousness and sensibility. Aquaculture, v.254, n.1-4, p.388-395, 2006. Available from: <http://www. sciencedirect.com/science/article/pii/S0044848605006320>. Accessed: Nov. 1, 2013. doi: 10.1016/j.aquaculture.2005.10.027.

LAMBOOIJ, E. et al. A humane protocol for electro-stunning and killing of Nile tilapia in fresh water. Aquaculture, v.275, n.1-4, p.88-95, 2008. Available from: <http://www.sciencedirect.com/ science/article/pii/S0044848608000318>. Accessed: Nov. 2, 2013. doi: 10.1016/j.aquaculture.2008.01.026.

LAMBOOIJ, E. et al. Percussion and electrical stunning of Atlantic salmon (Salmo salar) after dewatering and subsequent effect on brain and heart activities. Aquaculture, v.300, p.107-112, 2010. Available from: < http://www.sciencedirect.com/science/article/pii/ S0044848609009910>. Accessed: Nov. 4, 2018. doi: 10.1016/j. aquaculture.2009.12.022.

LAMBOOIJ, E. Electrical stunning. In: DIKEMAN, M.; DEVINE, C. (Org.). Encyclopedia of meat sciences. 2nd Edition ed. [S.1.]: Elsevier, p.1712, 2014. Available from: <https://www. sciencedirect.com/referencework/9780123847348/encyclopediaof-meat-sciences>. Accessed: Nov. 24, 2015.

LINES, J.; KESTIN, S. Electrical stunning of fish: the relationship between the electric field strength and water conductivity. Aquaculture, v.241, n.1-4, p.219-234, 2004. Available from: <http:// www.sciencedirect.com/science/article/pii/S0044848604004351>. Accessed: Feb. 27, 2014. doi: 10.1016/j.aquaculture.2004.07.023.

MANTHEY, M. et al. Quality changes of European catfish (Silurus glanis) from warm-water aquaculture during storage on ice. International journal of food science and technology, v.23, p.1-9, 1988. Available from: <https://ifst.onlinelibrary.wiley.com/ doi/abs/10.1111/j.1365-2621.1988.tb00543.x>. Accessed: Mar. 3, 2016. doi: 10.1111/j.1365-2621.1988.tb00543.x.

MENDES, J. M. et al. Influência do estresse causado pelo transporte e método de abate sobre o rigor mortis do tambaqui (Colossoma macropomum). Brazilian Journal of Food Technology, v.18, n.2, p.162-169, 2015. Available from: <https:/www.scielo.br/ scielo.php?script $=$ sci_arttext\&pid $=\mathrm{S} 1981-67232015000200162>$. Accessed: Nov. 30, 2015. doi: 10.1590/1981-6723.1115.

NORWAY. Animal Welfare Act. [S.1.], 2009. Available from: $<$ https://www.regjeringen.no/en/dokumenter/animal-welfare-act/ id571188/>. Accessed: Sep. 30, 2015.
OLIVEIRA FILHO, P. et al. How stunning methods affect the quality of Nile tilapia meat. CyTA - Journal of Food, v.13, n.May, p.56-62, 2014. Available from: <http://www.tandfonline.com/doi/ abs/10.1080/19476337.2014.911211>. Accessed: Feb. 27, 2015. doi: $10.1080 / 19476337.2014 .911211$.

OSTRENSKY, A. et al. Estudo setorial para consolidação de uma aquicultura sustentável no Brasil. Curitiba: [s.n.], 2007. Available from: <https://gia.org.br/portal/2007-estudo-setorialpara-consolidacao-de-uma-aquicultura-sustentavel-no-brasil/>. Accessed: Nov. 20, 2015.

PEDRAZZANI, A. et al. Impacto negativo de secção de medula e termonarcose no bem-estar e na qualidade da carne da tilápiado-Nilo. Revista Brasileira de Saúde e Produção Animal, v.10, n.1, p.188-197, 2009. Available from: <https://periodicos. ufba.br/index.php/rbspa/article/view/40244/22419>. Accessed: Nov. 9, 2013.

PIAIA, R. et al. Growth and survival of fingerlings of silver catfish exposed to different photoperiods. Aquaculture International, v.24, n.1, p.201-205, 1999. Available from: <https://link.springer. com/article/10.1023/A:1009299830102>. Accessed: Jan. 15, 2016. doi: 10.1023/A:1009299830102.

POLI, B. M. et al. Fish welfare and quality as affected by preslaughter and slaughter management. Aquaculture International, 2005. v.13, n.1-2, p.29-49. Available from: $<$ https://link.springer. com/article/10.1007\%2Fs10499-004-9035-1>. Accessed: Nov. 9, 2013. doi: 10.1007/s10499-004-9035-1.

ROBB, D. F.; ROTH, B. Brain activity of Atlantic salmon (Salmo salar) following electrical stunning using various field strengths and pulse durations. Aquaculture, v.216, p.363-369, 2003. Available from: <http://www.sciencedirect.com/science/article/ pii/S0044848602004945>. Accessed: Nov. 2, 2013. doi: 10.1016/ S0044-8486(02)00494-5.

ROBB, D. H. F. et al. Commercial slaughter methods used on Atlantic salmon: determination of the onset of brain failure by electroencephalography. Veterinary Record, v.147, n.11, p.298-303, 2000. Available from: $<$ https://pubmed.ncbi.nlm.nih.gov/11037730/>. Accessed: Nov. 6, 2019. doi: 10.1136/vr.147.11.298.

ROBB, D. H. F. et al. Electrical stunning of rainbow trout (Oncorhynchus mykiss): factors that affect stun duration. Aquaculture, v.205, n.3-4, p.359-371, 2002. Available from: $\quad<$ http://www.sciencedirect.com/science/article/pii/ S0044848601006779>. Accessed: Nov. 2, 2013. doi: 10.1016/ S0044-8486(01)00677-9.

ROBB, D. H. F.; KESTIN, S. C. Methods used to kill fish: field observations and literature reviewed. Animal welfare, v.11, p.269-282, 2002. Available from: <http://www.ingentaconnect. com/content/ufaw/aw/2002/00000011/00000003/art00001>. Accessed: Oct. 16, 2014.

RÖCKLINSBERG, H. Fish consumption: choices in the intersection of public concern, fish welfare, food security, human health and climate change. Journal of Agricultural and Environmental Ethics, v.28, p.533-551, 2015. Available from: <https://link. springer.com/article/10.1007\%2Fs10806-014-9506-y>. Accessed: Mar. 30, 2015. doi: 10.1007/s10806-014-9506-y.

ROSNER, B. Fundamentals of Biostatistics. 5 Edition, 2010. Accessed: Dec. 4, 2018. 
ROTH, B. et al. The effect of stunning methods on rigor mortis and texture properties of Atlantic Salmon (Salmo Salar). Journal of Food Science, v.67, n.4, p.1462-1466, 2002. Available from: <https://onlinelibrary.wiley.com/doi/ abs/10.1111/j.1365-2621.2002.tb10306.x>. Accessed: Jul. 5, 2014. doi: $10.1111 /$ j.1365-2621.2002.tb10306.x.

RUCINQUE, D. S. et al. Perception of fish sentience, welfare and humane slaughter by highly educated citizens of Bogotá, Colombia and Curitiba, Brazil. PLoS ONE, v.12, n.1, p.e0168197, 2017. Available from: <https://journals.plos.org/plosone/ article? id=10.1371/journal.pone.0168197>. Accessed: Apr. 2, 2018. doi: 10.1371/journal.pone.0168197.

RUCINQUE, D. S. et al. Electrical stunning in pacu (Piaractus mesopotamicus) using direct current waveform. Aquaculture, v.497, p.42-48, 2018. Available from: $<$ https://linkinghub.elsevier. com/retrieve/pii/S0044848618302928>. Accessed: Jul. 27, 2018. doi: 10.1016/j.aquaculture.2018.07.035.

SILVA, J. et al. Produção de Pacu em tanques-rede no reservatório de itaipu, Brasil: retorno econômico. Archivos de zootecnia, v.61, n.234, p.245-254, 2012. Available from: <https://www.uco.es/ucopress/az/index.php/az/article/ view/2798>. Accessed: Sep. 21, 2014. doi: 10.21071/ az.v61i234.2798.
TEJADA, M. ATP-derived products and K-value determination. In: REHBEIN, H.; OEHLENSCHLÄGER, J. Fishery products: quality, safety and authenticity. 1st. ed. John Wiley \& Sons, Cap.4, p.68-88, 2009. Available from: < https://www.researchgate. net/publication/229510203_ATP-Derived_Products_and_KValue_Determination>. Acessed: Sep. $21,201 \overline{4}$.

TERLOUW, C. et al. Consciousness, unconsciousness and death in the context of slaughter. Part I. Neurobiological mechanisms underlying stunning and killing. Meat Science, v.118, p.133-146, 2016. Available from: <https://www.sciencedirect.com/science/ article/abs/pii/S0309174016300705>. Accessed: Aug. 13, 2018. doi: 10.1016/j.meatsci.2016.03.011.

VEIT, J. C. et al. Influence of electronarcosis on behavioral responses, blood markers, and fillet properties of Silver Catfish (Rhamdia quelen). Journal of Aquatic Food Product Technology, 2017. v.26, n.3, p.308-324. Available from: <https:// www.tandfonline.com/doi/full/10.1080/10498850.2016.1170747> . Accessed: Jul. 27, 2018. doi: 10.1080/10498850.2016.1170747.

VAN DE VIS, J. W. et al. Stunning and killing of farmed fish: how to put it into practice? In: DIKEMAN, M.; DEVINE, C. Encyclopedia of meat sciences. 2nd. ed. [S.1.]: Elsevier, p.1712, 2014. Available from: <https://www.elsevier.com/books/encyclopedia-of-meatsciences/devine/978-0-12-384731-7>. Accessed: Dec. 18, 2015. 